\title{
First record of the Carboniferous trilobite Bollandia from the Moravian Karst (Czech Republic) and its significance
}

\author{
ŠTĚPÁN RAK \& RUDY LEROSEY-AUBRIL
}

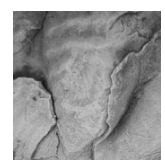

\begin{abstract}
The presence of bollandiine trilobites is reported for the first time in the early Carboniferous of Moravia, the Czech Republic. Bollandia persephone (Hahn \& Hahn, 1970) and B. cf. megaira (Hahn \& Hahn, 1970) were recovered from pelitic shales of late Tournaisian age within the Březina Formation exposed in Mokrá quarry, near Brno. Along with other taxa, these two species constitute a trilobite assemblage with few affinities to other Carboniferous associations known from the Czech Republic, but resemble an assemblage from the late Tournaisian of the Harz Mountains. Morphological characters of Bollandia species are interpreted as being indicative of an epibenthic mode of life, with possible adaptations for digging and for predatory/scavenging feeding habits. $\bullet$ Key words: Trilobita, Phillipsiidae, Bollandia, Carboniferous, palaeoecology, Moravian Karst.
\end{abstract}

RAK, Š. \& LEROSEY-AUBRIL, R. 2009. First record of the Carboniferous trilobite Bollandia from the Moravian Karst (Czech Republic) and its significance. Bulletin of Geosciences 84(4), 739-744 (3 figures). Czech Geological Survey, Prague. ISSN 1214-1119. Manuscript received July 16, 2009; accepted in revised form October 1, 2009; published online December 18, 2009; issued December 31, 2009.

Štěpán Rak (corresponding author), Charles University, Institute of Geology and Palaeontology, Albertov 6, 12843 Prague 2, Czech Republic; deiphon@ geologist.com • Rudy Lerosey-Aubril, Forschungsinstitut Senckenberg, Section Palaeozoology I, Senckenberganlage 25, D-60325 Frankfurt am Main,Germany; Rudy.Lerosey-Aubril@seckenberg.de

The first report of late Devonian and early Carboniferous trilobites from the Moravian Karst was by Rzehak (1910) who recorded an indeterminate proetid specimen from the probable Famennian of Líšeň, near Brno. Additional specimens subsequently found by Oppenheimer at this locality were described by Richter $(1912,1913)$.

During the 1950s, Chlupáč undertook extensive investigations in the Moravian Karst and reported the presence of Carboniferous trilobites from Hranice na Moravě (Chlupáč 1956) and Zbrašov na Moravě (Chlupáč 1958). In a comprehensive monograph on the Upper Devonian and Lower Carboniferous trilobites from Moravia (Chlupáč 1966), additional specimens found in a number of pits in the Hády-Ř́ička limestone sequence at Mokrá near Brno, as well as from previously known localities were described. To date, about 12 species representing 10 genera and 5 subfamilies have been recorded in the Carboniferous of Moravia, but hitherto, no representatives of the Bollandiinae have been found, although they are a common component of some Lower Carboniferous trilobite faunas from other parts of Europe.

Here we report the recent discovery of the genus Bollandia in the Early Carboniferous section of the Mokrá quarry within the Moravian Karst (Fig. 1). This area has yielded a particularly diversified fossil assemblage dominated by trilobites which are dated to the latest Tournaisian-earliest Viséan, Gnathodus interzone according to conodonts and upper part of zone 8 to lower part of zone 9 according to foraminifera (Devuyst \& Hance in Poty et al. 2006; Kalvoda et al. 2009). Twelve species of trilobites have been identified, of which the majority were previously unknown from the Moravian Karst (Rak 2004). Among these there are eight fragmentary specimens which belong to two species of Bollandia: B. persephone (Hahn \& Hahn, 1970) and B. cf. megaira (Hahn \& Hahn, 1970). The specimens were recovered from pelitic shales and show clear evidence of dorsoventral and lateral deformation. However, preservation is sufficient to enable comparison with the type material of these species from coeval carbonate sequences (Erdbach Limestone) in the Harz Mountains.

\section{Systematic palaeontology}

The specimens described herein form part of Š. Rak's collections deposited in the Czech Geological Survey, Praha (SR 2-9). Abbreviations used are: exs. - exsagittal; sag. sagittal; tr. - transverse. 


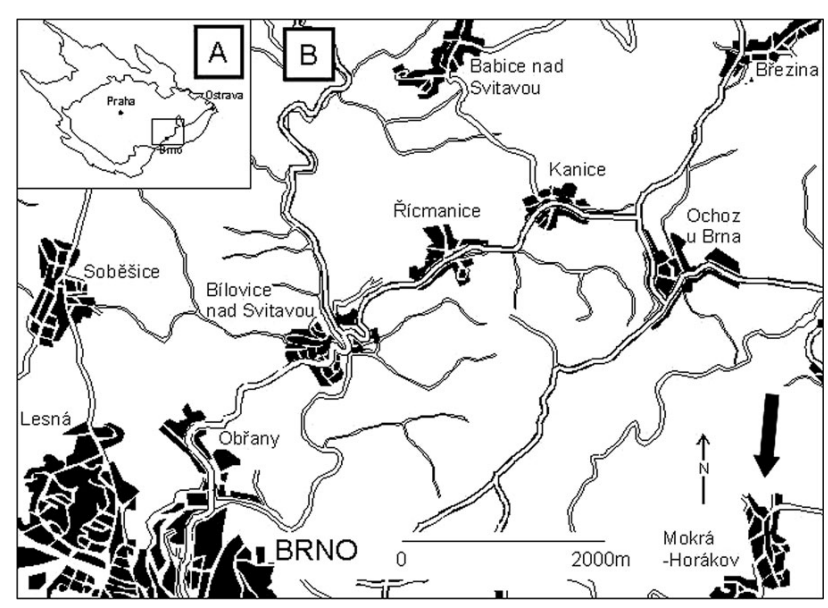

Figure 1. A - location of Moravian Karst region within the Bohemian Massif and the Czech Republic. • B - location of Mokrá quarry (arrowed).

Family Proetidae Hawle \& Corda, 1847

Subfamily Bollandiinae Hahn \& Brauckmann, 1988

\section{Genus Bollandia Reed, 1943}

Type species. - Asaphus globiceps Phillips, 1836, County Kildare, Ireland; Carboniferous, Tournaisian (Courceyan) (for a review, see Owens 2000).

Diagnosis. - See Hahn \& Hahn (1971).

Assigned species. - B. albae (Gandl, 1977); B. alekto (Hahn \& Hahn, 1970); B. claviceps (Burmeister, 1846); B. columba Tilsley, 1988; B. eudora Hahn \& Hahn, 1992; B. frechi (Scupin, 1900); B. gerehahnorum Müller, 2007; B. kirgisiana Osmólska, 1970; B. globiceps (Phillips, 1836); B. granulifera (Phillips, 1836); B. megaira (Hahn \& Hahn, 1970); B. obsoleta (Phillips, 1836); B. persephone (Hahn \& Hahn, 1970); B. persephonoides Hahn, Hahn \& Müller, 2003; B. proserpina Hahn, Hahn \& Müller, 1998; B. rugiceps Tilsley, 1988; B. sonkulensis Osmólska, 1970; B. tisiphone (Hahn \& Hahn, 1970); B. torionis (Gandl, 1977). Tentatively assigned: B. ?karatauensis (Weber, 1937).

Occurrence. - Late Tournaisian to Viséan, Asia (Kyrgyzstan, ?Turkey), Europe (Belgium, Czech Republic, France, Germany, Great Britain, Ireland, Poland, Russia, Spain), and North America (Alaska).

Bollandia persephone (Hahn \& Hahn, 1970) Figures 2A-K, 3

1966 Griffithides sp. - Hahn, pp. 349, 350. 1967 Griffithides sp. - Hahn, pp. 183, 184.
1970 Griffithides (Bollandia) persephone; Hahn \& Hahn, pp. 211, 212.

1971 Griffithides (Bollandia) persephone; Hahn \& Hahn, pp. 136-141, figs 16-19, pl. 26, figs 19-24.

1975 Griffithides (Bollandia) persephone; Hahn \& Hahn, p. 60 , pl. 9 , fig. 10a, b.

1977 Griffithides (Bollandia) persephone; Gandl, p. 190.

2003 Bollandia persephone; Hahn, Hahn \& Müller, p. 60 .

Material. - Two incomplete cranidia, five incomplete pygidia, Moravia, SR 3-9.

Locality. - Mokrá quarry, Moravian Karst, near Brno, the Czech Republic (Fig. 1).

Horizon. - Pelitic shales, Březina Formation. Late Tournaisian, Carboniferous.

Description. - S1 deep, straight, rather shallow and broad, and running inwardly and obliquely towards SO but without reaching it; SO straight, narrow, rather deep sagittally, but shallowing laterally; LO wide (tr.), of almost equal length (sag. and exs.) throughout, and bearing a tiny occipital node; palpebral lobe apparently narrow (tr.), widest opposite mid-length of L1. In lateral profile, glabella strongly inflated anteriorly. Sculpture: posterior threequarters of glabella are covered with granules that progressively merge into terrace ridges on the anteriormost quarter.

Pygidium of semicircular outline; axis moderately wide, transversely convex, posterior end apparently reaching border furrow; 8 particularly broad, shallow inter-ring furrows delimiting $8+1$ raised axial rings; pleural field bearing up to five pleural ribs with narrow pleural furrows that divide them into flat anterior bands and more convex posterior bands; pleural and interpleural furrows terminate at the border which is moderately convex, rather wide posteriorly but narrowing anteriorly. Sculpture: small tubercules on pygidial border.

Remarks. - These specimens are assigned to Bollandia persephone (Hahn \& Hahn, 1970) because they are similar to the type specimens in the following features: the sculpture of the glabella, the straight, broad, shallow S1, the proportions, convexity and general outline of the pygidium, the number of axial rings, depth of the axial and inter-ring furrows, number and organization of pleural ribs, and the relative width of pygidial border. Minor differences are the slightly wider (tr.) glabella and pygidium and a less inflated pygidial axis. These can be accounted for by intraspecific variation, and possibly also taphonomic deformation. 


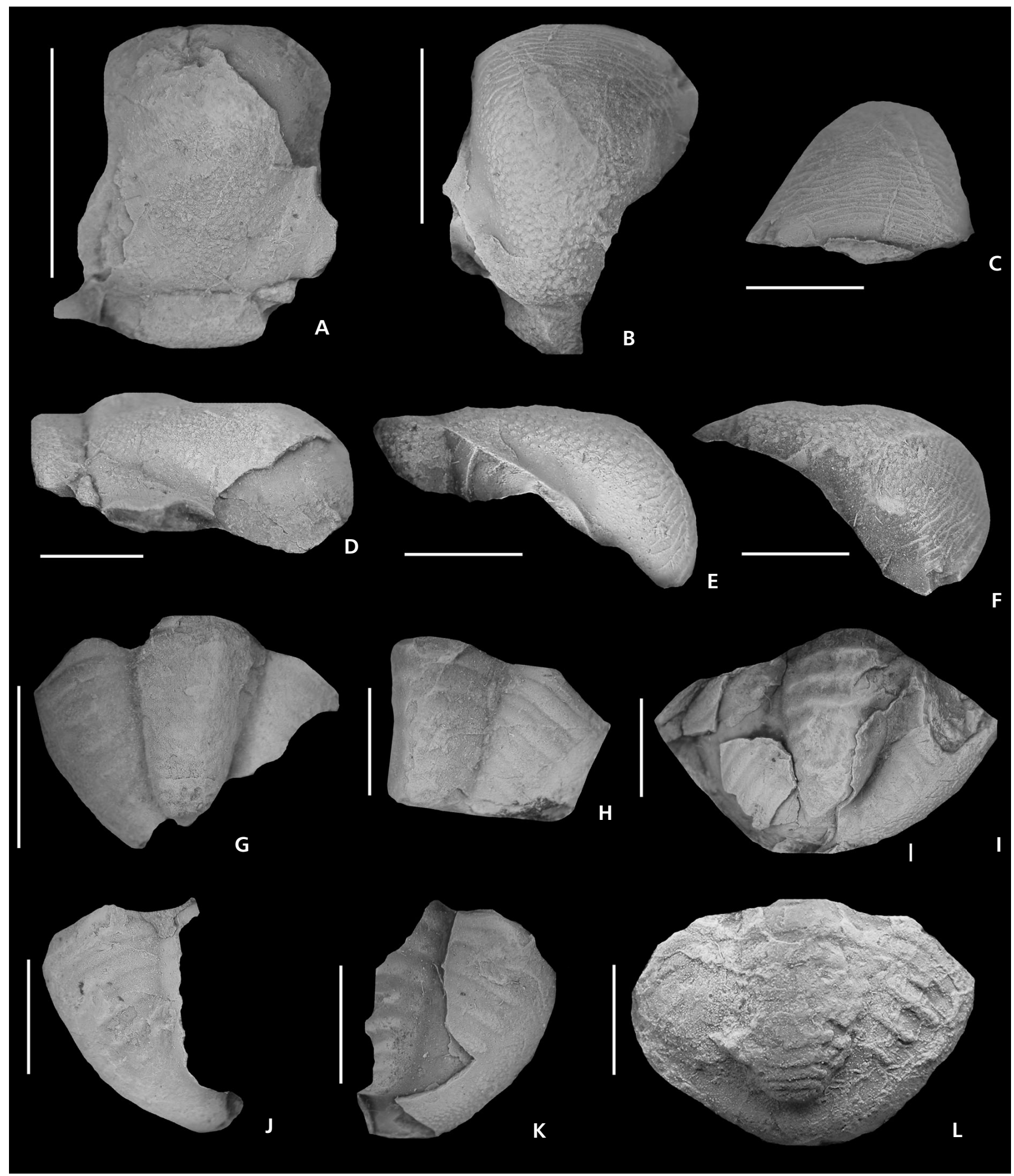

Figure 2. A-K - Bollandia persephone (Hahn \& Hahn, 1970). A, D - incomplete cranidium in dorsal and right lateral views, SR3. $\bullet$ B, C, E, F-incomplete cranidium in dorsal, anterior, left lateral and right lateral views (note the terrace ridges on the frontal lobe of the glabella), SR4. $\bullet$ G-K - incomplete pygidia, dorsal views: G - SR5; H - SR6; I - SR7; J - SR9; K - SR8. • L - Bollandia cf. megaira, weathered pygidium, dorsal view, SR2. Scale bars represent $5 \mathrm{~mm}$. All specimens from the late Tournaisian, Březina Formation, Mokrá quarry, Moravian Karst, the Czech Republic. 


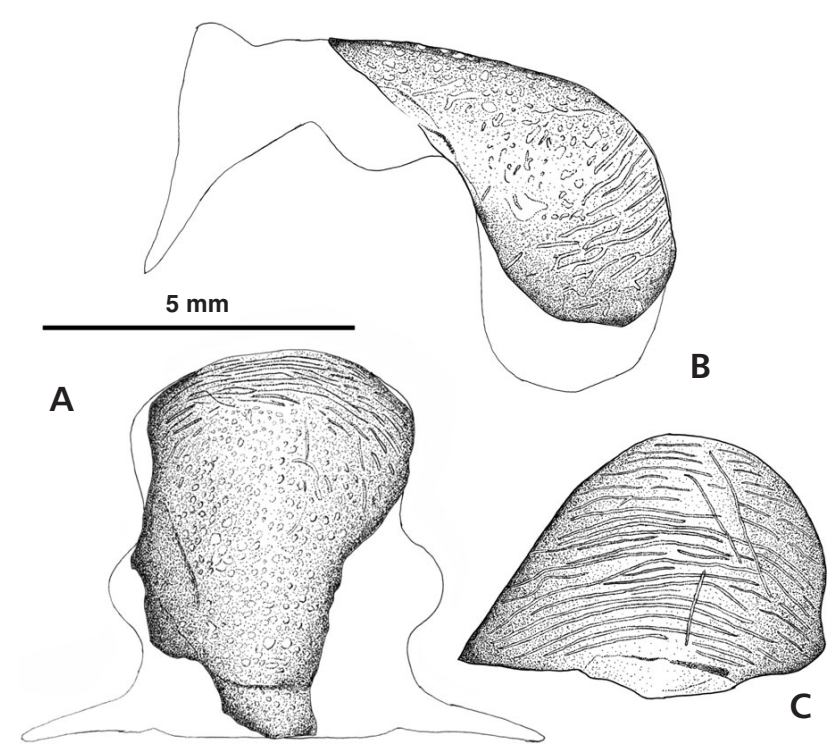

Figure 3. Bollandia persephone (Hahn \& Hahn, 1970) from the late Tournaisian, Březina Formation, Mokrá quarry, Moravian Karst, the Czech Republic. Interpretative drawings of an incomplete cranidium (SR4), showing tubercles merging into terrace ridges on the anterior part of the glabella (arrowed). A - dorsal, B - lateral and C - anterior views. Scale bar represents $5 \mathrm{~mm}$.

\section{Bollandia cf. megaira (Hahn \& Hahn, 1970) Figure 2L}

Material. - A single weathered pygidium (Fig. 2L), SR2.

Locality. - Mokrá quarry, Moravian Karst, near Brno, the Czech Republic (Fig. 1).

Horizon. - Pelitic shales, Březina Formation. Late Tournaisian, Carboniferous.

Description. - Axis long (about three-quarters of the sagittal length of the pygidium) and rather wide (about a third of the anterior width (tr) of the pygidium), moderately tapering and rounded posteriorly, subdivided into $8+1$ axial rings by deep and broad inter-ring furrows; axial furrows deep; pleural field moderately convex and bearing 5 deep pleural furrows and 4 shallow interpleural furrows which die out before reaching the border furrow; pygidial border wide, convex, without terrace ridges. Sculpture: as far as can be determined, pygidium entirely smooth.

Remarks. - This pygidium is similar to that of B. megaira (Hahn \& Hahn 1971, pl. 27, fig. 38) in its proportions and vaulting, the number of axial rings, the depth of axial and inter-ring furrows, its rather wide border, and in the absence of sculpture. Because we have only one incompletely preserved specimen, we have placed it in open nomenclature; additional material is required for confident specific determination.

\section{Remarks on the autecology of Bollandia}

The exoskeleton of Bollandia exhibits some morphological traits which are potentially informative with regard to the autecology of this trilobite. The frontal lobe of the glabella is inflated, and overhangs the anterior border. This morphology suggests that the hypostome was probably 'secondarily attached' in this taxon in the impendent mode (Fortey 1990, pp. 538, 543), a character which has been associated to scavenging/predatory habits in trilobites (Fortey \& Owens 1999, p. 434). To our knowledge, the morphology of the Bollandia hypostome is known only from a single specimen figured by Woodward (1884, pl. 6, fig. 5) and is now believed to be lost (see Owens 2000, p. 21). If Woodward's attribution is correct, the wide anterior margin of this hypostome suggests that it was firmly attached to the cephalic doublure ['buttressed hypostome' sensu Fortey \& Owens (1999), p. 433]. Along with the apparently pointed posterolateral angles, this supports the view that Bollandia had scavenging/predatory feeding habits (Fortey \& Owens 1999, pp. 436, 437). Lastly, the strong $\mathrm{S} 1$ and inflated L1 might be regarded as indicative of significant musculature enabling rather complex movements of the underlying appendages. As far as we know, these appendages were most likely located adjacent to the mouth (Bruton \& Haas 1997, text-figs 23a, 25), and thus it seems reasonable to speculate that the characteristics of the posterior part of the glabella in this trilobite were also related to specific feeding habits, possibly scavenging/predatory.

The size of eyes in Bollandia varies from one species to another, but the visual surface is always vertical and displays strong convexity antero-posteriorly, and to a lesser extent dorso-ventrally (e.g., Osmólska 1970, pl. 1, fig. 10; Owens 2000, fig. 5). This indicates the visual field of this trilobite was relatively wide, but mainly in a horizontal plane (e.g., at least $180^{\circ}$ in B. globiceps, see fig. 5D in Owens 2000), dorsal vision being more limited. Consequently, it seems reasonable to assume that Bollandia lived on the sea-floor instead of being endobenthic. However, the development of structures resembling terrace ridges on the anterior part of the glabella in $B$. persephone (Figs 2B, C, E, F, 3A-C) might indicate adaptation for digging in this species (Schmalfuss 1981). In this regard, $B$. persephone resembles some scutelluids with vaulted exoskeleton, such as the Early Devonian Paralejurus (e.g., $P$. rehamnanus, Schraut \& Feist 2004, fig. 7) or the Frasnian Telopeltis (especially T. woodwardi, McNamara \& Feist 2006, fig. 3.1-6), which have been regarded as semiendobenthic forms (Schraut \& Feist 2004, Feist \& Lerosey-Aubril in press). Bollandia generally exhibits a wide axis and rather vaulted exoskeleton which might confirm some digging adaptations. However, whether it dug to conceal part of its body within the substrate, or to feed from endobenthic organisms cannot be determined. 


\section{Conclusion}

The discovery of new trilobites within the Březina Formation in Mokrá quarry will substantially enhance our current knowledge of Moravian Carboniferous trilobites. In this paper, the occurrence of Bollandiinae in Moravia is documented for the first time which demonstrates the obvious palaeogeographical affinities of Czech trilobite assemblages with other European Carboniferous faunas, especially those of the Harz Mountains (Hahn et al. 1998, 2003). However, further investigation is required to determine precisely to which faciesconstrained associations the new Moravian fauna corresponds, for example those from Belgium and Germany (Hahn 1990).

As recently demonstrated quantitatively (LeroseyAubril \& Feist in press), Tournaisian times represented a major period of diversification for trilobites following the late Famennian Hangenberg extinction event. The associated adaptive radiation is clearly illustrated by the emergence of morphological characteristics, such as those of Bollandia, which have no known equivalents in Famennian trilobites. We interpret the morphological characteristics of Bollandia as indicative of an epibenthic mode of life, with possible adaptations for digging, and for predatory/scavenging feeding habits. This is just one example of the great ecological diversity exhibited by trilobites in the early Carboniferous, but a full assessment of this must await detailed quantitative analysis of trilobite disparity at that time. A typical trilobite associationcomparable to the association described from Erdbacher Kalken in Steeden, Hessen (Germany) - was found during the excavations in Mokrá quarry. It consists of the following taxa:

Cyrtoproetus (Cyrtoproetus) cracoensis cracoensis (Reed 1899),

Semiproetus (Macrobole) drewerensis latipalpebratus (Osmólska, 1973),

Liobole (Panibole) sp., and

Linguaphillipsia sp.

Among the associated faunal components collected, there were also isolated valves of brachiopods, ossicles and columns of crinoids as well as limited remains of other groups of fossils.

\section{Acknowledgements}

We are grateful to Carsten Brauckmann and Jiří Kalvoda for their valuable comments and kind assistance during this study. Our sincere gratitude goes to the reviewers Raimund Feist, Robert Owens and Petr Budil. Štěpán Rak also thanks the Grant Agency of the Czech Academy of Science for its financial support through project No. 42-201 598.

\section{References}

BURMEISTER, H. 1846. The organisation of trilobites, deduced from their living affinities, with a review of the species hitherto described. 136 pp. The Ray Society, London.

BRUTON, D.L. \& HAAS, W. 1997. Functional morphology of Phacopinae (Trilobita) and the mechanics of enrollment. $\mathrm{Pa}$ laeontographica, Abteilung A 245, 1-43.

CHLUPÁČ, I. 1956. Nález spodnokarbonské fauny u Hranic na Moravě. Věstník Ústředního ústavu geologického 31, 268-273.

CHLUPÁČ, I. 1958. Nová spodnokarbonská fauna od Zbrašova u Hranic na Moravě. Sborník Ústředního ústavu geologického, Oddíl paleontologický 24, 279-312.

CHLUPÁČ, I. 1966. The Upper Devonian and Lower Carboniferous trilobites of the Moravian karst. Sborník geologických věd, Paleontologie 7, 1-143.

FEIST, R. \& LEROSEY-AUBRIL, R. in press. Coaptatives devices, enrollment, and life habits in Paralejurus, a particular case in scutelluid trilobites. Palaeobiodiversity and Palaeoenvironment.

FORTEY, R.A. 1990. Ontogeny, hypostome attachment and trilobite classification. Palaeontology 33, 529-576.

FORTEY, R.A. \& OWENS, R.M. 1999. Feeding habits in trilobites. Palaeontology 42, 429-65. DOI 10.1111/1475-4983.00080

GANDL, J. 1977. Die Karbon-Trilobiten des Kantabrischen Gebirges (NW-Spanien), 2: Die Trilobiten der Alba-Schichten (Unter-Visé bis Namur A). Senckenbergiana lethaea 58, $113-217$.

HAHN, G. 1966. Morphologie, Variabilität und postlarvale Ontogenie von Archegonus (Phillibole) nitidus und Archegonus (Angustibole) winterbergensis (Trilobita, Unter-Karbon). Senckenbergiana lethaea 47, 347-383.

HAHN, G. 1967. Neue Trilobiten vom Winterberg/Harz (UnterKarbon). Senckenbergiana lethaea 48, 163-189.

HAHN, G. 1990. Intercontinental correlation and division of the Carboniferous system. Lower Carboniferous boundaries. Palaeobiogeographic distribution and biostratigraphic significance of Lower Carboniferous trilobites: a review. Courier Forschungsinstitut Senckenberg 130, 199-205.

HAHN, G. \& BRAUCKMANN, C. 1988. Zur Phylogenie der Bollandiinae (Trilobita, Karbon-Perm. Jahresberichte des Naturwissenschaftlichen Vereins in Wuppertal 41, 119-131.

HAHN, G. \& HAHN, R. 1970. Trilobitae carbonici et permici II. (Proetidae: Griffithidinae). Fossilium Catalogus I: Animalia 119: 161-331.

HAHN, G. \& HAHN, R. 1971. Revision von Griffithides (Bollandia). (Tril.; Unter-Karbon). Palaeontographica, Abteilung A 137, 109-154.

HAHN, G. \& HAHN, R. 1975. Die Trilobiten des Ober-Devon, Karbon und Perm, I-VIII, 1-127. In KRÖMMELBEIN, K. (ed.) Leitfossilien 1. Gebrüder Borntraeger, Berlin \& Stuttgart.

HAHN, G. \& HAHN, R. 1992. Trilobiten aus dem Karbon von SE-Alaska, Teil 2. Geologica et Palaeontologica 26, 99-133.

Hahn, G., HAHn, R. \& MÜlleR, P. 1998. Trilobiten aus den Erdbacher Kalken (Unter-Karbon) von Steeden in Hessen. Geologica et Palaeontologica 32, 161-219.

Hahn, G., HAhn, R. \& MÜlleR, P. 2003. Trilobiten aus den 
Erdbacher Kalken (Unter-Karbon) von Steeden in Hessen Teil 2. Geologica et Palaeontologica 37, 33-75.

HAWLE, I. \& CORDA, A.J.C. 1847. Prodrom einer Monographie der böhmischen Trilobiten. Böhmischen Gesellschaft der Wissenschaften, Abhandlungen 5, 1-176.

KAlvodA, J., DEVUYST, F.X., BÁBEK, O., DVOŘÁK, L., RAK, S. \& REZ, J. 2009. High resolution biostratigraphy of the Tournaisian-Viséan boundary interval, Mokrá Quarry, Czech Republic. Geobios, accepted.

LEROSEY-Aubril, R. \& FEIST, R. In press. Quantitative approach of diversity and decline in Late Palaeozoic trilobites. In TALENT, J.A. (ed.) Global Biodiversity, Extinction Intervals and Biogeographic Perturbations through Time. Springer, Berlin.

MCNAMARA, K.J. \& FEIST, R. 2006. New styginids from the Late Devonian of Western Australia - the last corynexochid trilobites. Journal of Paleontology 80, 981-992. DO1 10.1666/0022-3360(2006)80[981:NSFTLD]2.0.CO;2

OSMÓLSKA, H. 1970. Revision of non-cyrtosymbolinid trilobites from the Tournaisian-Namurian of Eurasia. Palaeontologia Polonica 23, 1-165.

OWENS, R.M. 2000. The Carboniferous trilobites from Ireland described by Phillips, Portlock, McCoy and Woodward. Irish Journal of Earth Sciences 18, 1-32.

PHILLIPS, J. 1836. Illustrations of the geology of Yorkshire, Part 2, the Mountain Limestone District. 253 pp. Murray, London.

Poty, E., Devuyst, F.X. \& HANCE, L. 2006. Upper Devonian and Mississippian foraminiferal and rugose coral zonations of Belgium and Northern France: a tool for Eurasian correlations. Geological Magazine 143(6), 829-857. DOI $10.1017 / \mathrm{S} 0016756806002457$
RAK, Š. 2004. Trilobitová fauna hraničních vrstev tournai-visé z. Mokré u Brna. 67 pp. Master thesis, Masaryk University, Brno, Czech Republic.

REED, F.R.C. 1943. The genera of British Carboniferous trilobites. Annals and Magazine of Natural History 10, 54-65.

RICHTER, R. 1912. Beiträge zur Kenntnis devonischer Trilobiten. Erster Beitrag. Die Gattung Dechenella und einige verwandte Formen. Abhandlungen der Senckenbergischen Naturforschenden Gesellschaft 31, 239-340.

RZEHAK, A. 1910. Der Brünner Clymenienkalk. Zeitschrift des Mährischen Landesmuseum 10, 149-216.

SCHMALFUSS, H. 1981. Structure, patterns and function of cuticular terraces in trilobites. Lethaia 14, 311-341. DOI 10.1111/j.1502-3931.1981.tb01107.x

SChraUt, G. \& FEIST, R. 2004. The Devonian styginid Paralejurus, with new data from Spain and Morocco. Journal of Paleontology 78, 709-722.

DOl 10.1666/0022-3360(2004)078<0709:TDSTPW>2.0.CO;2

SCUPIN, H. 1900. Die Trilobiten des niederschleisichen Unterkarbon. Zeitschrift der Deutschen geologischen Gesellschaft $1,1-22$.

TILSLEY, J.W. 1988. New data on Carboniferous (Dinantian) trilobites from the Peak District, Derbyshire, England. Proceedings of the Yorkshire Geological Society 47, 163-176.

WEBER, V.N. 1937. Trilobites of the Carboniferous and Permian system of USSR. 1. Carboniferous trilobites. Palaeontology of USSR Monographs 71, 1-159.

WOODWARD, H. 1883-84. A monograph of the British Carboniferous trilobites. Monographs of the Palaeontographical Society of London 37-38, 1-86. 